\title{
Energy Potential of Solid Waste Generated in Landmark University, Omu- Aran, Kwara State Nigeria
}

\author{
${ }^{1 *}$ Oladejo, O. S, ${ }^{1}$ Abiola, A. O, ${ }^{1}$ Olanipekun, A. A, ${ }^{2}$ Ajayi, O. E and ${ }^{3}$ Onokwai, A. O \\ ${ }^{1}$ Department of Civil Engineering, Ladoke Akintola University of Technology, Ogbomoso, Nigeria \\ ${ }^{2}$ Department of Civil Engineering, Landmark University, Omu-Aran, Nigeria \\ ${ }^{3}$ Department of Mechanical Engineering, Landmark University, Omu-Aran, Nigeria \\ *Correspondence Author: osoladejo@lautech.edu.ng 08035770398
}

\begin{abstract}
This study aims at determining the energy content from campus wastes and estimation of electricity generation. Samples of solid wastes generated within Landmark University were collected, separated, classified, dried in the oven at $105^{\circ} \mathrm{C}$ till constant weight was attained, pulverized and sieved using a sieve size of $500 \mu \mathrm{m}$. The moisture contents of the waste samples were determined, in triplicates. The digital bomb calorimeter (C-200 Bomb Calorimeter) was used to determine the calorific value of the prepared waste samples. Correlation analysis was carried out to determine coefficients and significant levels; while regression equations were generated, using ANOVA to relate the dependent variable Potential Electricity Generated (PEG) with independent variables- Total Energy Content (TEC) and Specific Energy Content (SEC). The moisture contents are plastic bottles (0.78\%), water sachet (0.82\%), and food packs (5.37\%), wood wastes and ash (5.35\%), food wastes $(5.95 \%)$, and paper wastes $(5.56 \%)$. Calorific values of plastic bottles, polythene products, Wood wastes and ash, food wastes, paper wastes and polystyrene (food pack) are 31,246.63, $29,084.24,17,243.56,14,360.49,12,975.42$ and $4575.10 \mathrm{~kJ} / \mathrm{kg}$, respectively. The total energy content from the campus wastes was estimated at 32,999.30 MJ/day. This implies a possibility of about 0.38MW of electricity generation from daily steam production. There was high level of correlation between the energy value parameters $(R>0.99)$ and significant at $<0.01$. The energy content is expected to grow with the expansion of the campus.
\end{abstract}

Keywords: Campus wastes, Correlation analysis, Energy content, Electricity generation, Moisture content, Regression equations.

\section{Introduction}

The economic, social and intellectual development of any nation is hinged on energy generation. With about ninety percent of fossil fuel- derived energy, and its inimical effects on human health and the environment, great challenge was posed in meeting the demand of the global energy demand. Waste to energy (WtE) remains one of the sustainable ways of energy generation. This involves any forms of treatment that convert combustible waste materials to energy in form of electricity or heat (Adeniran et al., 2019)

There are notable variations in the nature of solid waste generation with country, city, suburb, and seasons and with time as styles and patterns of living change. The variation characteristics can be determined precisely only by analysis in each particular case.

In his nationwide comprehensive waste generation survey, Oyinlola (1998) reported that higher quantities of wastes were generated by high income earners compared to the lowincome households. He mentioned World Bank reports on variations in per capital waste 
generation between low income, middle income and high income or industrialized countries as $0.4-0.6 \mathrm{~kg} /$ day, $0.5-0.9 \mathrm{~kg} /$ day, and $0.7-1.8 \mathrm{~kg}$ /day, respectively. Daskalopoulos and Probert (1998) opined that there will always be concerns for the disposal of massive refuse, in some of the developing countries, where management of municipal wastes are inadequate. This bothers on the elementary and undeveloped methods and operations of municipal waste management techniques, coupled with lack of appropriate data and information about the types and quantities of wastes generated, collected, amount recovered and possible locations of wastes disposal sites (Aguilar-virgen et al., 2010). The management of solid waste in Nigeria has been one of the greatest challenges facing the tiers of government. The government environmental agencies have not been able to improve on the financial and technical resources needed to match with the challenge of ever-increasing volume of the solid waste being generated.

Solid waste management in Nigeria is characterized by inefficient collection methods, insufficient coverage of the collection system and improper disposal of solid waste. As such, most cities and towns are characterized by waste disposal dumpsites situated on any available free land roads streets, drainages (Amber et al., 2012). In Nigeria, for example, added to the problem of inadequate municipal waste management operations is the erratic power supply from the national grid, making the fast depleting fossil fuels and firewood remain the main nation's energy sources (Ikuponisi, 2006). The capital-intensive renewable energy sources such as biogas, solar, wind, thermal and nuclear sources have not been holistically implemented to solve the problem of insufficient energy. However, available alternative energy sources derivable from municipal solid wastes are environment friendly and cheaper. While serving presently as source of electricity generation, the environment is also made clean. Impact of waste scavengers in Ilorin, Nigeria has been investigated by Adeyemi et al., (2004). The energy content of ten agricultural wastes in Nigeria farmlands was determined and reported in Jekayinfa and Omisakin (2005) in accordance with the method of Association of Official Analytical Chemists. Oladejo et al., (2018) studied solid waste generation, characteristics and material recovery potentials for landmark university campus.

In our present world, many institutions of higher learning were synonymous to minor cities, with large expanse of land bigger than many towns, activities of various dimensions by humans which have numerous effects on the total environment. Many Universities in Nigeria have been said to act as their own municipalities (Adeniran et al. 2017). The situation in Landmark University is not an exception. Oladejo et al. (2018) reported that about two tonnes $(1785.4 \mathrm{~kg})$ total solid wastes generated per day with generation rate of $0.36 \mathrm{~kg} / \mathrm{person} / \mathrm{day}$. Wastes generation from residential, academic/administrative and utility zones was 1599.8, 103.9 and $81.7 \mathrm{~kg} /$ day respectively. Oladejo et al. (2020) documented clean energy generation and material recovery potentials from solid wastes generated in Omu Aran community as the effect of poor waste management is inimical to the environment and our health. Some of the negative effects are foul odour, environmental pollution, respiratory problems due to air pollution, food poisoning via soil and water pollution. A major antidote to mitigate poor management of waste is characterization, as reported by Oladejo et al. (2018) from the previous studies carried out on solid waste characterization from Landmark University campus. 
Incineration processes require the knowledge of the chemical composition of the available solid wastes. The most important properties of interest are (i) Proximate analysis (ii) Fusing point of ash (iii) Ultimate analysis (iv) Heating value. The amount of heat produced during fuel combustion at constant pressure at normal conditions of $25^{\circ}$ and 1 atmosphere is referred to as the fuel heating value. The combustion process produces water (vapour or steam). Rominiyi et al. (2017). Presently, Landmark University has not adopted any energy extraction method or value addition system to address the final waste disposal options. However, the current energy gap in Nigeria calls for alternative energy sources. Thus, the aim of this study is to determine the energy contents and estimation of electricity in the solid wastes generated from Landmark University as an integral approach to municipal solid waste management.

\section{Materials and Methods}

Solid wastes generated within the study area, Landmark university campus (as described in Oladejo et al. 2018) were obtained from waste collection containers. The determination of weight of the physical components was carried out daily for a period of 5 days, a week within six months (between December, 2017 and May, 2018). This was from Monday to Friday. The wastes were sorted and weighed into material types which included paper, cardboard, plastic bottles, metals cans, food wastes, polythene bags, polystyrene food pack, e-wastes, sanitary and ash residuals.

To determine the percentage moisture content (MC) in the campus wastes, the solid waste samples categorized into combustible components and non-combustible components were dried in the oven at $105^{\circ} \mathrm{C}$ till constant weight was attained, pulverized (the organic part of the constituents) and sieved with a mesh size of 500 micron. The experiment was carried out in the Mechanical Engineering laboratory of Landmark University and was evaluated using ASTM D3173 procedure (ASTM, 1988). Samples

And the $\%$ moisture content of samples determined as thus:

$\% \mathrm{MC}$ in the solid waste: $\frac{w 2-w 3}{w 2-w 1} \times 100$

Where:

$\mathrm{w}_{1}$ is the container mass

$\mathrm{W}_{2}$ is the container mass + wet mass of the solid waste sample.

$\mathrm{W}_{3}$ is the initial mass of the solid waste.

The Calorific Value (CV) of the residual waste is expressed as energy content (E), or heat value, released when burnt in air. The Net Calorific value (NCV), or Lower Heating Value (LHV) was used in the evaluations of sample. The NCV was measured in terms of the energy content per unit mass (García et al., 2012).

$\mathrm{E}(\mathrm{MJ})=\mathrm{M} \times \mathrm{NCV}$

Where $\mathrm{NCV}$ is net calorific value and $\mathrm{M}$ is the sample mass. i.e.

Energy Content $=$ Quantity of MSW generated $(\mathrm{Kg}) \times$ Specific Energy Content $(\mathrm{MJ} / \mathrm{Kg})$

The evaluation of the energy content of Landmark University solid waste was determined using ASTM E711-87- Standard Test Method for Calorific Value of Refuse-Derived Fuel by 
Bomb Calorimeter (The Cal 2k-Eco Calorimeter), (ASTM, 2004) in the Mechanical Engineering laboratory of Landmark University.

Electricity Generation Potential $(\mathrm{MW})=\frac{H}{24 \times 3600}$

Where $\mathrm{H}$ is the Total Energy Content (MJ/day) of the Combustible Components of campus Solid Waste (CSW).

Correlation analysis was carried out to determine coefficients and significant levels; while mathematical equations were generated, using ANOVA to relate the dependent variable with independent variables, using Statistical Package for Social Sciences 16.0 (SPSS).

\section{Results and Discussion}

Results

This study was designed to evaluate the energy content of the solid waste in the Landmark university campus. Table 1 showed the daily solid waste generation, classification and characteristics within Landmark University campus, while the results of the moisture and energy contents from campus solid wastes was presented in Table 2. Moisture contents and energy values of combustible components of the campus wastes was shown in Figure 1. Figure 2 presented estimated electricity generation of combustible components of the campus wastes. Table 3 showed the correlation coefficients between Potential electricity generated and energy value parameters of combustible components of campus wastes, whiles the regression equations relating Potential Electricity Generated (PEG) with Total Energy Content (TEC) and Specific Energy Content (SEC) of solid waste generated in Landmark University campus was presented in Table 4.

Discussion

Daily solid waste generation on campus ranged between $1655.34 \mathrm{~kg}$ to 1947.32 , with daily average value of $1785.4 \mathrm{~kg}$ as reported by Oladejo et al. (2018) and shown in Table 1.

The \% moisture content (MC) of samples was presented in Table 2 and varied within $0.8 \%$ and $5.95 \%$. This could be attributed to the effect of constituent wastes in each of the samples. As reported in Figure 1, plastic bottles and polythene sachets components which had the least $\mathrm{MC}$ values possessed the highest values of specific energy contents. Quaghebeur et al., (2013) and Adelopo et al., (2017) have attributed the non- porous nature of plastic and polythene materials as a major compositional factor affecting the moisture content of composite municipal waste. Bingh (2004) and Cheng et al. (2007) also identified high moisture content of waste as having significant effect on its combustibility. The $\%$ moisture content of samples in this study was within permissible condition for waste to energy of less than $45 \%$ as reported by Cheng and $\mathrm{Hu}$ (2010) and central pollution control, (2016).

As presented in Table 2, highest calorific value was recorded in plastic bottles, $31,246.63 \mathrm{~kJ} / \mathrm{kg}$, followed by polythene products (water sachet nylons) with value of $29,084.24 \mathrm{~kJ} / \mathrm{kg}$. Wood waste and ash was $17,243.56 \mathrm{~kJ} / \mathrm{kg}$, while food waste has heating value of $14,360.49 \mathrm{~kJ} / \mathrm{kg} .12,975.42 \mathrm{~kJ} / \mathrm{kg}$ was recorded in paper and the least specific energy content of $4575.10 \mathrm{~kJ} / \mathrm{kg}$ was found in polystyrene (food pack) waste. Similar trend was noticed in Adeniran et al. (2019). All the combustible components of the campus wastes 
considered in this work, except polystyrene (food pack, $4.58 \mathrm{MJ} / \mathrm{kg}$ ) were above the minimum energy level of $6 \mathrm{MJ} / \mathrm{kg}$ for viable WtE feed (World bank, 1999). As at present, when the solid waste stream in Landmark University is completely burnt per day to produce steam, $0.38 \mathrm{MW}$ of electricity can be generated. This is quite very low to what was obtained when the municipal solid waste stream in Ado-Ekiti is completely burnt per day to produce steam, where $51.50 \mathrm{MW}$ of electricity can be generated (Rominiyi et al., 2017).

The energy potential of waste recoverable was affected by the variations in waste components (Figure 2). Cheng et al., 2007 also observed that variations in the energy contents of waste largely affect the energy generation. Low energy content waste $(4-6.7 \mathrm{MJ} / \mathrm{kg}$ ) from food waste reduced the energy generation while higher energy generation were obtained from WtE due to relative higher energy content waste like polythene materials.

In community like University campus, waste generation and variations are confined majorly to the campus activities, which are expected to be minimal compared to variations expected in Municipal Solid Waste (MSW) (Okeniyi et al., 2012). Hoornweg and Bhada-Tata, (2012) reported that level of education, income statute, life styles are major factors influencing the type of waste generated

The life style of people with tertiary education and thus earning income above average, which eventually traceable to the most populous within the University campus, has been reported as having attribute of generating large quantity of non- biodegradable (Irwan et al., 2011). The reports of Armijo de Vega et al. (2008), Smyth et al. (2010), Okeniyi et al. (2012) and Oladejo, et al. (2018) from the studies of waste characterization within university campuses, had studied waste characterization of university campuses confirmed the generation of large quantity of non- biodegradable.

The potential energy generated could be attributed to the moisture contents, specific and total energy contents of the constituent wastes. This was investigated using a correlation studies between potential electricity generated and energy value parameters of combustible components of solid waste generated in Landmark University campus (Table 3). The study showed that moisture content had a strong negative statistical correlation of $R>-0.897$ and significant at $\mathrm{P}$ values of $<0.05$. This indicated that moisture content decreases with increased potential energy generated. However, the specific and total energy contents had very strong positive statistical correlations of $\mathrm{R}>0.885$ and 0.998 and significant at $\mathrm{P}$ values of $<0.05$ and $<0.01$, respectively. The regression equations relating Potential Electricity Generated (PEG) with Total Energy Content (TEC) and Specific Energy Content (SEC) of solid waste generated in Landmark University campus were also expressed in Table 4.

The statistical analyses of the data generated from the combustible components of solid waste generated in Landmark University campus showed high level of correlation between the potential electricity generated and energy value parameters of the combustible components. 
The total energy content and the estimated electricity value of waste in the present work is an indication of waste utilization as an alternative renewable energy source. The wastes are reflected as free source and therefore economical to use as source of energy. This is a clean source of green energy for electricity production.

Table 1: Daily Solid Waste generation, classification and characteristics within Landmark University campus (Oladejo et al. (2018)

\begin{tabular}{|c|c|c|c|c|c|c|c|c|c|c|c|c|}
\hline Day & Paper & Organic & Wood & Polystyrene & Plastic & Polythene & Metals & Glass & E-waste & Residuals & Sanitary & Total (kg) \\
\hline 1-Monday & 202 & 427.6 & 38.29 & 87.8 & 341.6 & 511.56 & 155.47 & 0.75 & 4.8 & 114.45 & 63 & 1947.32 \\
\hline 2-Tuesday & 213.49 & 361.6 & 41.76 & 95.81 & 301.45 & 511.85 & 175.97 & 0 & 9 & 26.27 & 63 & 1800.2 \\
\hline 3-Wednesday & 209.52 & 425.2 & 28.76 & 84.44 & 345.3 & 405.63 & 187.43 & 0 & 18.18 & 31.45 & 47 & 1782.91 \\
\hline 4-Thursday & 211.91 & 394.26 & 24.47 & 82.35 & 258.1 & 376.37 & 201.81 & 1.05 & 8.07 & 43.95 & 53 & 1655.34 \\
\hline 5-Friday & 203.72 & 341.71 & 33.71 & 93.66 & 290.24 & 402.85 & 174.46 & 0 & 22.62 & 66.25 & 63 & 1692.22 \\
\hline Total (kg) & 1040.64 & 1950.37 & 166.99 & 444.06 & 1536.69 & 2208.26 & 895.14 & 1.8 & 62.67 & 282.37 & 289 & 8877.99 \\
\hline Average & 208.13 & 390.07 & 34.2 & 88.81 & 316.3 & 441.65 & 179.03 & 0.36 & 12.53 & 56.47 & 57.8 & 1785.4 \\
\hline $\mathbf{N}=\mathbf{5}$ & \pm 5.05 & \pm 38.11 & \pm 6.99 & \pm 5.80 & \pm 36.63 & \pm 64.96 & \pm 17.14 & $\pm \mathbf{0 . 5 0}$ & \pm 7.51 & \pm 35.89 & \pm 7.43 & \\
\hline \% Average & 11.7 & 21.9 & 1.9 & 5 & 17.7 & 24.7 & 10 & 0.02 & 0.7 & 3.18 & 3.2 & 100 \\
\hline
\end{tabular}

Table 2: The combustible components of solid waste generated in Landmark University campus

\begin{tabular}{|c|c|c|c|c|c|c|c|}
\hline $\mathbf{S} / \mathbf{N}$ & $\begin{array}{l}\text { Combustible } \\
\text { Components }\end{array}$ & $\begin{array}{l}\text { \% } \\
\text { Composition }\end{array}$ & $\begin{array}{l}\text { Moisture } \\
\text { content (\%) } \\
\mathbf{N}=\mathbf{3}\end{array}$ & $\begin{array}{l}\text { Quantity of } \\
\text { MSW generated } \\
\text { (kg/day) } \\
\mathrm{N}=5\end{array}$ & $\begin{array}{l}\text { Specific } \\
\text { Energy } \\
\text { Content } \\
(\mathbf{k J} / \mathrm{Kg}) \\
\end{array}$ & $\begin{array}{l}\text { Total } \\
\text { Energy } \\
\text { Content } \\
\text { (MJ/day)* }\end{array}$ & $\begin{array}{l}\text { Electricity } \\
\text { generation } \\
\text { Potential } \\
(\mathrm{MW})^{*}\end{array}$ \\
\hline 1. & Paper & 11.7 & $5.54 \pm 0.01$ & $208.13 \pm 5.05$ & $12,975.42$ & $2,700.57$ & 0.03 \\
\hline 2. & Food Wastes & 21.9 & $5.95 \pm 0.01$ & $390.07 \pm 38.11$ & $14,360.49$ & $5,600.59$ & 0.06 \\
\hline 3. & Wood waste and Ash & 5.08 & $5.35 \pm 0.03$ & $90.67 \pm 40.88$ & $17,243.56$ & $1,563.47$ & 0.02 \\
\hline 4. & Food Pack & 5.0 & $5.37 \pm 0.01$ & $88.81 \pm 5.80$ & 4575.10 & 406.31 & 0.01 \\
\hline 5. & Plastic Bottles & 17.7 & $0.78 \pm 0.01$ & $316.3 \pm 36.63$ & $31,246.63$ & $9,883.31$ & 0.11 \\
\hline 6. & Water Sachet & 24.7 & $0.80 \pm 0.1$ & $441.65 \pm 64.96$ & $29,084.24$ & $12,845.05$ & 0.15 \\
\hline Total & & 85.98 & & 1535.63 & $109,485.44$ & $32,999.30$ & 0.38 \\
\hline
\end{tabular}

$* \mathrm{MW}=1.15740741 \times 10^{-5} \mathrm{MJ} / \mathrm{day}$ 


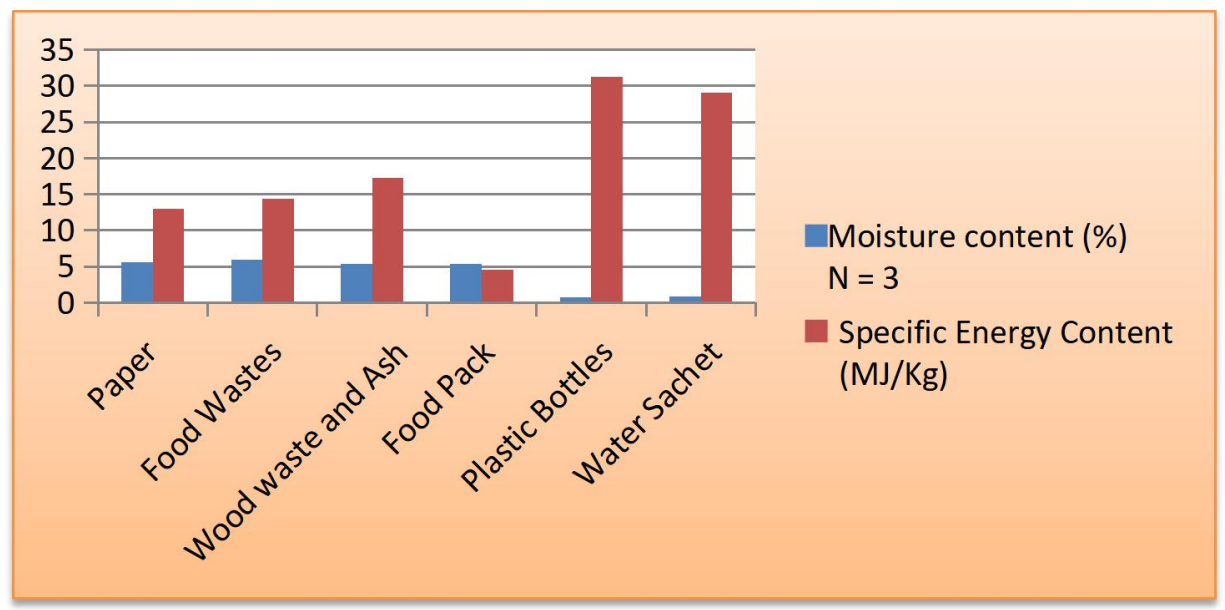

Figure 1: Moisture contents and energy values of combustible components of the campus wastes

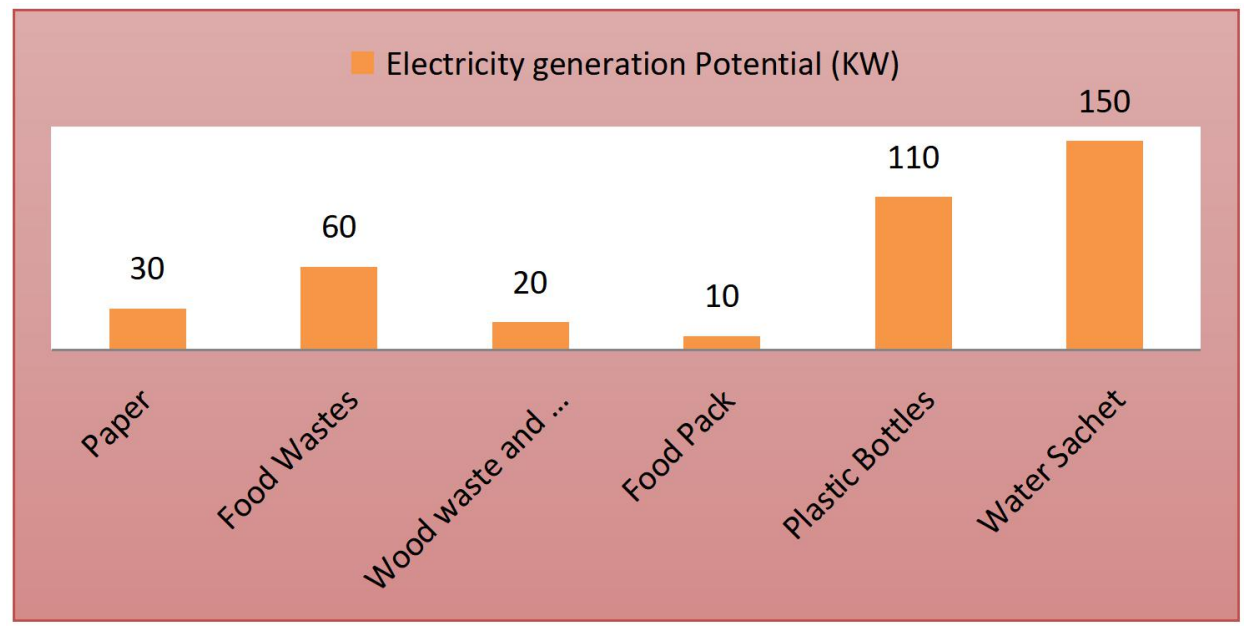

Figure 2: Estimated electricity generation of combustible components of the campus wastes 
Table 3: The correlation coefficients between Potential electricity generated and energy value parameters of combustible components of solid waste generated in Landmark University campus

\begin{tabular}{|c|c|c|c|c|c|c|}
\hline & $\begin{array}{l}\text { \% } \\
\text { composition of } \\
\text { combustibles }\end{array}$ & $\begin{array}{l}\text { Moisture } \\
\text { content }\end{array}$ & $\begin{array}{l}\text { Quantity } \\
\text { of CSW }\end{array}$ & $\begin{array}{l}\text { Specific } \\
\text { energy } \\
\text { content }\end{array}$ & $\begin{array}{l}\text { Total } \\
\text { energy } \\
\text { content }\end{array}$ & $\begin{array}{l}\text { Potential } \\
\text { Electricity } \\
\text { generated }\end{array}$ \\
\hline $\begin{array}{l}\text { \% composition } \\
\text { of combustibles }\end{array}$ & 1 & & & & & \\
\hline $\begin{array}{l}\text { Moisture } \\
\text { content }\end{array}$ & -.563 & 1 & & & & \\
\hline $\begin{array}{l}\text { Quantity of } \\
\text { CSW }\end{array}$ & $1.000^{* *}$ & -.566 & 1 & & & \\
\hline $\begin{array}{l}\text { Specific energy } \\
\text { content }\end{array}$ & .647 & $-.895^{*}$ & .649 & 1 & & \\
\hline $\begin{array}{l}\text { Total energy } \\
\text { content }\end{array}$ & $.877^{*}$ & $-.884^{*}$ & $.879^{*}$ & $.892^{*}$ & 1 & \\
\hline $\begin{array}{l}\text { Potential } \\
\text { Electricity } \\
\text { generated }\end{array}$ & $.858^{*}$ & $-.897^{*}$ & $.860^{*}$ & $.885^{*}$ & $.998^{* *}$ & 1 \\
\hline
\end{tabular}

**Correlation is significant at the 0.01 level (2-tailed).

*Correlation is significant at the 0.05 level (2-tailed).

Table 4: The regression equations relating Potential Electricity Generated (PEG) with Total Energy Content (TEC) and Specific Energy Content (SEC) of solid waste generated in Landmark University campus

\begin{tabular}{|c|c|c|c|c|}
\hline \multicolumn{5}{|c|}{ Regression coefficients } \\
\hline $\begin{array}{l}\text { Pairs of } \\
\text { parameters }\end{array}$ & $\mathbf{R}$ & $\mathbf{A}$ & $\mathbf{b}$ & Regression equations \\
\hline PEG vs TEC & 0.998 & 0.002 & $1.124 \times 10^{-5}$ & $1.124 \times 10^{-5} \mathrm{TEC}+0.002$ \\
\hline PEG vs SEC & 0.885 & -0.025 & $4.847 \times 10^{-6}$ & $4.847 \times 10^{-6} \mathrm{SEC}-0.025$ \\
\hline
\end{tabular}




\section{Conclusion}

1. Plastic bottles, Polythene and paper products, and wood wastes have the high calorific value hence a high potential to produce steam to generate electricity.

2. The statistical analyses of the data generated from the combustible components of solid waste generated in Landmark University campus showed high level of correlation between the potential electricity generated and energy value parameters of the combustible components.

3. Based on the findings in this study, Landmark University has potentials for renewable energy recovery through incineration of the organic components of solid waste generated on campus. This eventually, contributes positively to the energy supply, and cleaner environment.

4. Detailed studies that cover various seasons should be carried out to underscore effects of seasonal variations on energy generated from solid wastes. Also, further studies need to be conducted on assessing the potential of various agricultural wastes in production of bio-fertilizer and fuels.

\section{References}

Adelopo, A.O., Haris, P.I., Alo, B., Huddersman, K., Jenkins, R.O. 2017.Seasonal variations in moisture content and the distribution of total organic carbon in landfill composites: case of active and closed landfills in Lagos, Nigeria. Int. J.Environ. Waste Manage. 20(2), 171-185.

Adeniran, A. E., Nubi, A. T. and Adelopo, A. O. (2017) "Solid waste generation and characterization in the University of Lagos for a sustainable waste management", Waste Management, 67: 3- 10.

Adeniran, A. E., Adelopo, A. O., Aina, A. T., Nubi, A. T. and Apena, O. O. (2019). Energy Potential of Solid Waste Generated at a Tertiary Institution: Estimations and Challenges. Detritus, 07: 4-12.

Adeyemi A. S, Olorunfemi J. F. and Adewoye T. O. (2004). Waste scavenging in third world cities: A case study of Ilorin, Nigeria, The Environmentalist. Springer Netherlands, 21(2): 93-96.

Aguilar-Virgen Q, Armijo-de Vega C, Taboada-González P. A, Ojeda-Benítez S. (2010) Municipal solid waste generation and characterization in Ensenada, Mexico. The Open Waste Management Journal, 3: 140-145.

Amber, I., Kulla, D. M. and Gukop, N. (2012) Generation, characteristics and energy potential of solid municipal waste in Nigeria. Journal of Energy in Southern Africa, 23(3): 47- 51.

Armijo de Vega, C., Ojeda Benitez, S., Ramirez Barreto, M.E. 2008. Solid waste haracterization and recycling potential for a university campus. Waste Manage. 2(Suppl. 1), S21-S26.

ASTM D3173.1988. Standard Test Method for Determination of the Composition of Unprocessed Municipal Solid Waste, ASTMA standard 5231-5292 (Reapproved 1998), American Society for Testing and Materials, USA.

ASTM E711-87 2004. Standard Test Method for Gross Values of Refuse-Derived Fuel by the Bomb Calorimeter (Re-approved), American Society for Testing and Materials, West Conshohocken, PA.

Bingh L. P (2004). Opportunities for utilising waste biomass for energy in Uganda. Master's thesis, Department of Energy and Process Engineering, Norwegian University of Science and Technology.

Cheng, H., Zhang, Y., Meng, A., Li, Q .2007. Municipal solid waste fuelled power generation in China: a case study of waste-to-energy in Changchun city. Environ. Sci. Technol. 41, 75097515 
Cheng, H. and $\mathrm{Hu}$ Y. 2010. Municipal solid waste (MSW) as a renewable source of energy: Current and future practices in China. Bioresource Technology 101, 3816-3824.

Central Pollution Control Board. 2016. Selection Criteria for Waste Processing Technologies. Ministry of Environment, Forests and Climate Change. Parivesh Bhawqan, East Arjun Nagar, Shahdara: Ministry of Environment, Forests and Climate Change.

Daskalopoulos, B. O. and Probert S.D. (1998). An integrated approach to municipal solid waste management. Journal of Resources, Conservation and Recycling, 24(1): 33-50.

García, R., Pizarro C., Lavín, A. G., Bueno, J.L.2012. Characterization of Spanish biomass wastes for energy use, Bioresource Technology, 103, 249-258.

Hoornweg, D. and Bhada-Tata, P. 2012. What a waste: a global review of solid waste management, World Bank, Washington DC, USA.

Ikuponisi F. S. (2006) Status of renewable energy in Nigeria. An International Conference on Making Renewable Energy a Reality. One Sky- Canadian Institute of Sustainable Living, 21-27.

Irwan, D., Basri, E. A., Watanabe, K. 2011. Interrelationship between affluence and household size on municipal solid waste arising: evidence from selected Residential areas of putrajaya. Journal of Asian Scientific Research 2,747-758

Jekayinfa S. O, Omisakin O. S. (2005). The energy potentials of some agricultural wastes as local fuel materials in Nigeria, Agricultural Engineering International: The CIGR EJournal VII, Manuscript EE 05003.

Okeniyi, J.O. Anwan, E.U., Okeniyi, E.U. 2012. Waste Characterization and Recoverable Energy potential Using waste generated in model community in Nigeria. Journal of Environmental Science and Technology 5(4), 232-240.

Oladejo, O. S., Auta, A. M., Ibikunle, D. I and Omamofo, E. K (2018) Solid Waste Generation, Characteristics and Material Recovery Potentials for Landmark University Campus, International Journal of Civil Engineering and Technology, 9 (9): 1071-1082.

Oladejo, O. S., Ilesanmi, O. T., Olanipekun, A, A, and Ajayi, O. E. (2020). Clean energy generation and material recovery potentials from solid wastes generated in Omu Aran community. IOP Conf. Ser.: Earth Environ. Sci. (445) 012053

Oyinlola, A. K. (1998) Waste preserves and recycling. Proceedings of Urban Solid Waste Management Scheme, Abuja 22 ${ }^{\text {nd }}$ - 25th November, 152.

Quaghebeur, M., Laenen, B., Geysen, D., Nielsen, P., Pontikes, Y.2013. Characterization of landfilled materials: screening of the enhanced landfill mining potential. J. Clean. Prod. 55, 72-83.

Rominiyi, O. L, Fapetu, O. P., Owolabi, J. O. and Adaramola, B. A (2017) Determination of Energy Content of the Municipal Solid Waste of Ado - Ekiti Metropolis, Southwest, Nigeria. CJAST, 23(1): 1-11.

Smyth, D.P., Fredeen, A.L., Booth, A.L.2010. Reducing solid waste in higher education: the first step towards 'greening' a university campus. Resource Conservation Recycling 54, 10071016.

World Bank.1999. Technical Guidance Report on Municipal Solid Waste Incineration, The International Bank for Reconstruction and Development, Washington, D.C. 20433, U.S.A. 